\title{
Discovery of Ceratosphaeridium (Acritarcha) from the Ediacaran Doushantuo Formation in Yangtze Gorges, South China and its biostratigraphic implication
}

\author{
Penguu Liu, Chongyu Yin, Shouming Chen, Feng TANg \& LinZHI GaO
}

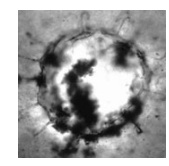

\begin{abstract}
Ceratosphaeridium Grey, 2005 is a key taxon of ECAP (Ediacaran complex acritarch palynoflora) in the Officer and Amadeus basins, South Australia. Recently, several specimens of Ceratosphaeridium were fortuitously observed from the Member III of the Ediacaran Doushantuo Formation in the Yangtze Gorges, South China. The discovery of Ceratosphaeridium and other associated acritarchs from the Doushantuo Formation suggests that this taxon is widely distributed and with potential for inter-continental correlation of Ediacaran strata. Acritarch assemblages in Member III of the Doushantuo Formation in Yangtze Gorges can now be correlated with the Ediacaran Complex acantrhiomorph palynoflora (ECAP) of South Australia. At present, the ECAP cannot be correlated with the lower microfossil assemblage of the Ediacaran Doushantuo Formation of the Yangtze Gorges (characterized by the key taxon Tainzhushania and this interval may be missing in South Australia. $\bullet$ Key words: Ediacaran, Acritarcha, Yangtze Gorges, South Australia, Ceratosphaeridium, stratigraphical correlation.
\end{abstract}

LiU, P.J., Yin, C.Y., CHEN, S.M., TANG, F. \& GAO, L.Z. 2012. Discovery of Ceratosphaeridium (Acritarcha) from the Ediacaran Doushantuo Formation in Yangtze Gorges, South China and its biostratigraphic implication. Bulletin of Geosciences 87(1), 195-200 (3 figures). Czech Geological Survey, Prague. ISSN 1214-1119. Manuscript received September 12, 2010; accepted in revised form February 10, 2012; published online February 29, 2012; issued February 29, 2012.

Pengju Liu, Chongyu Yin, Shouming Chen, Feng Tang \& Linzhi Gao, Institute of Geology, Chinese Academy of Geological Sciences, Beijing, 100037, China; pengju@cags.net.cn

Acritarchs belong to an informal group of microorganisms with mostly unknown phylogenic origins (Evitt 1963). It is commonly agreed that they are polyphyletic and many are considered to be resting cysts of single-celled, eukaryotic phytoplankton. Since acritarchs are widespread and evolved rapidly, they are widely used for Phanerozoic biostratigraphy. Previous studies suggest that acritarch records in Ediacaran successions show rapid diversification and replacement of taxonomically diverse assemblages over short intervals (Knoll \& Ohta 1988, Yin \& Liu 1988, Vidal 1990, Knoll 1992, Zang \& Walter 1992, Moczydłowska et al. 1993, Tiwari \& Knoll 1994, Yuan \& Hofmann 1998, Zhang et al. 1998, Grey 2005, Moczydłowska 2005, Veis et al. 2006, Willman et al. 2006, Zhou et al. 2007, Willman \& Moczydłowska 2008). Some Ediacaran acritarch taxa, such as Papillomembrana compta and Tanarium conoideum, seem to have short stratigraphic ranges and a wide distribution on several palaeocontinents; thus their potential for Ediacaran biostratigraphic subdivision and global correlation is becoming increasingly important.
Four assemblage zones of the Ediacaran complex acanthomorphic acritarch palynoflora (ECAP) were identified in the Officer and Amadeus basins, South Australia and Northern Territory, and to a lesser extent on the Stuart Shelf, adjacent to the Adelaide Rift Complex of South Australia (Grey et al. 2003, Grey 2005). These distributions were confirmed in subsequent studies by Willman et al. (2006) and Willman \& Moczydłowska (2008). Among them, the genus Ceratosphaeridium, characterized by a single process is one of the most important taxa of ECAP in the Officer and Amadeus basins, South Australia. Recently, several specimens of Ceratosphaeridium were fortuitously found from the Ediacaran Doushantuo cherts in the Yangtze Gorges, South China (Fig. 1). Prior to this report, the specimens of genus Ceratosphaeridium have only been found in the Officer and Amadeus basins, South Australia. So, the discovery of Ceratosphaeridium from the Doushantuo chert suggests that this taxon is widely distributed and with potential for inter-continental correlation of Ediacaran strata. 

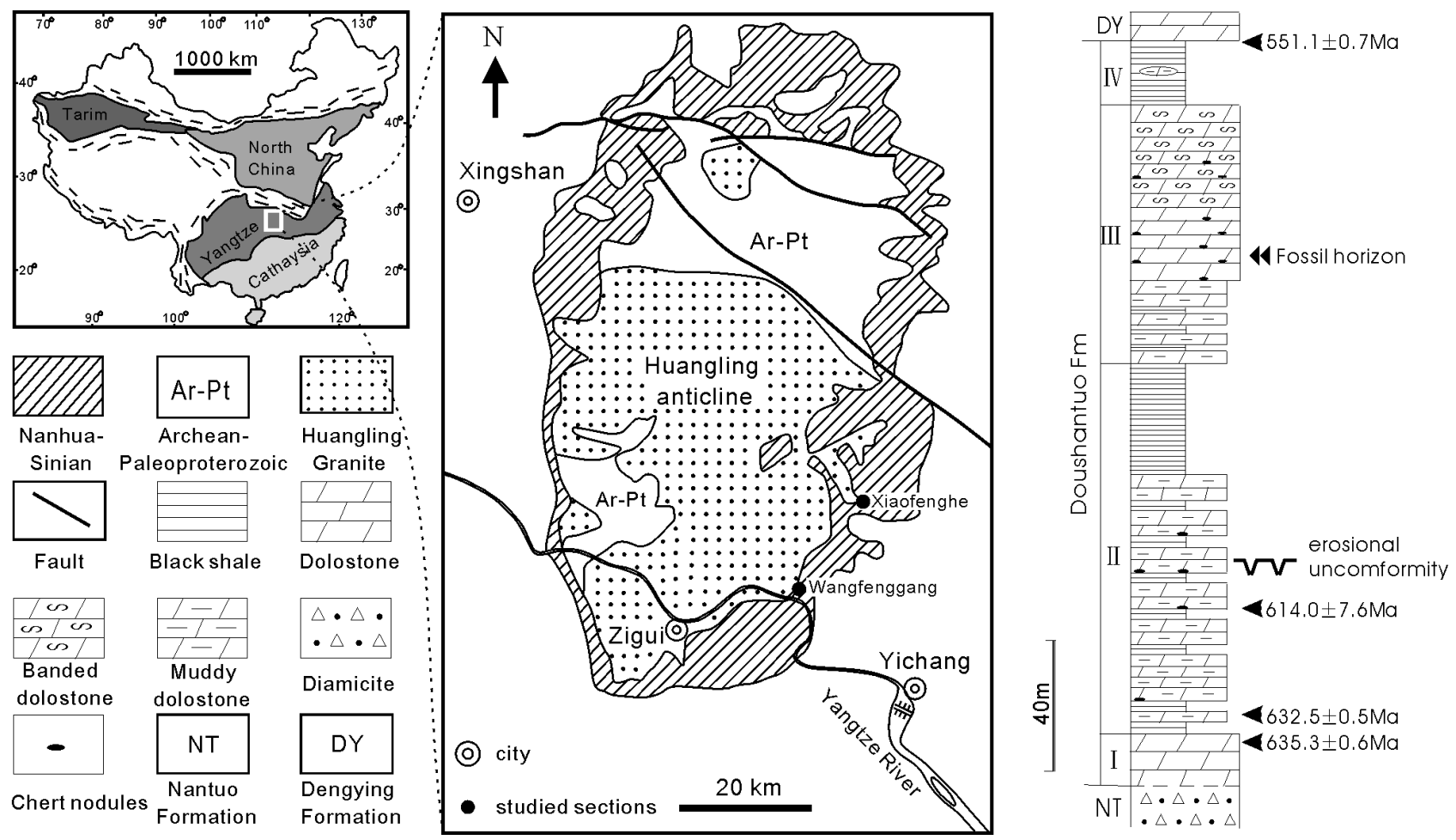

Figure 1. Simplified geologic map of the Yangtze Gorges area and general stratigraphy of the Doushantuo Formation.

\section{Ceratosphaeridium in Yangtze Gorges, South China}

\section{Ediacaran stratigraphy of Yangtze Gorges, South China}

Due to an abundance of fossils and a long research history, the Ediacaran succession in the Yangtze Gorges, South China, is one of the most important Ediacaran successions in the world. The Ediacaran Doushantuo Formation in South China is underlain by the Cryogenian Nantuo diamictite and overlain by upper Ediacaran dolostone of the Dengying Formation. The age of the Doushantuo Formation has been constrained between $635.2 \pm 0.6 \mathrm{Ma}$ and $551.1 \pm 0.7 \mathrm{Ma}$ (Fig. 1) by zircon U-Pb ages obtained from interbedded ash beds (Condon et al. 2005, Yin et al. 2005, Zhang et al. 2005). Generally, the Doushantuo Formation in the Yangtze Gorges area consists of four members. These members are, in ascending order, (1) $\sim 5 \mathrm{~m}$ thick cap carbonate overlying glacial deposits of the Nantuo Formation; (2) 80-120 m thick black shale intercalated with medium-bedded dolostone and muddy dolostone with abundant chert nodules; one obvious erosional unconformity (younger than $614.0 \pm 7.6 \mathrm{Ma}$; Liu et al. 2009a) can be seen in the middle part of this member at many sections (Zhu et al. 2007); (3) 40-60 m thick medium-bedded dolostone with chert bands or lenticles and banded dolostone; (4) 10 m thick black shale with large dolomitic concretions (Fig. 1).
Previous studies indicated that the Doushantuo Formation in the Yangtze Gorges area was deposited in subtidal environments and the chert nodules were formed just below the water-sediment interface during early diagenesis (Xiao 2004). Abundant silicified microfossils, including acritarchs, coccoidal and filamentous cyanobacteria, multicellular algae, embryos and some tubular microfossils have been reported from chert nodules or lenticles in both Member II and III (Zhang et al. 1998, Yin 1999, Xiao 2004, Yin et al. 2007, Zhou et al. 2007, Liu et al. 2009b). Black shales of Member IV at Miaohe (see Fig. 1 for location) contain abundant macroscopic carbonaceous compressions (Chen et al. 1994, Xiao et al. 2002, Tang et al. 2008). In addition, large numbers of Chuaria-like carbonaceous compressions and a dichotomously branching algal thallus (Entermorphites see Zhu \& Chen 1984) were found from black shales in Member II at the Jiulongwan section (see Fig. 1 for location, Tang et al. 2006). The reported specimens of Ceratosphaeridium were found from the lower part of Member III at the Wangfenggang and Xiaofenghe sections (see Fig. 1 for location).

\section{Ceratosphaeridium in the Yangtze Gorges and its taxonomy}

The genus Ceratosphaeridium was established by Grey (2005) based on specimens found from the Wilari Dolomite 

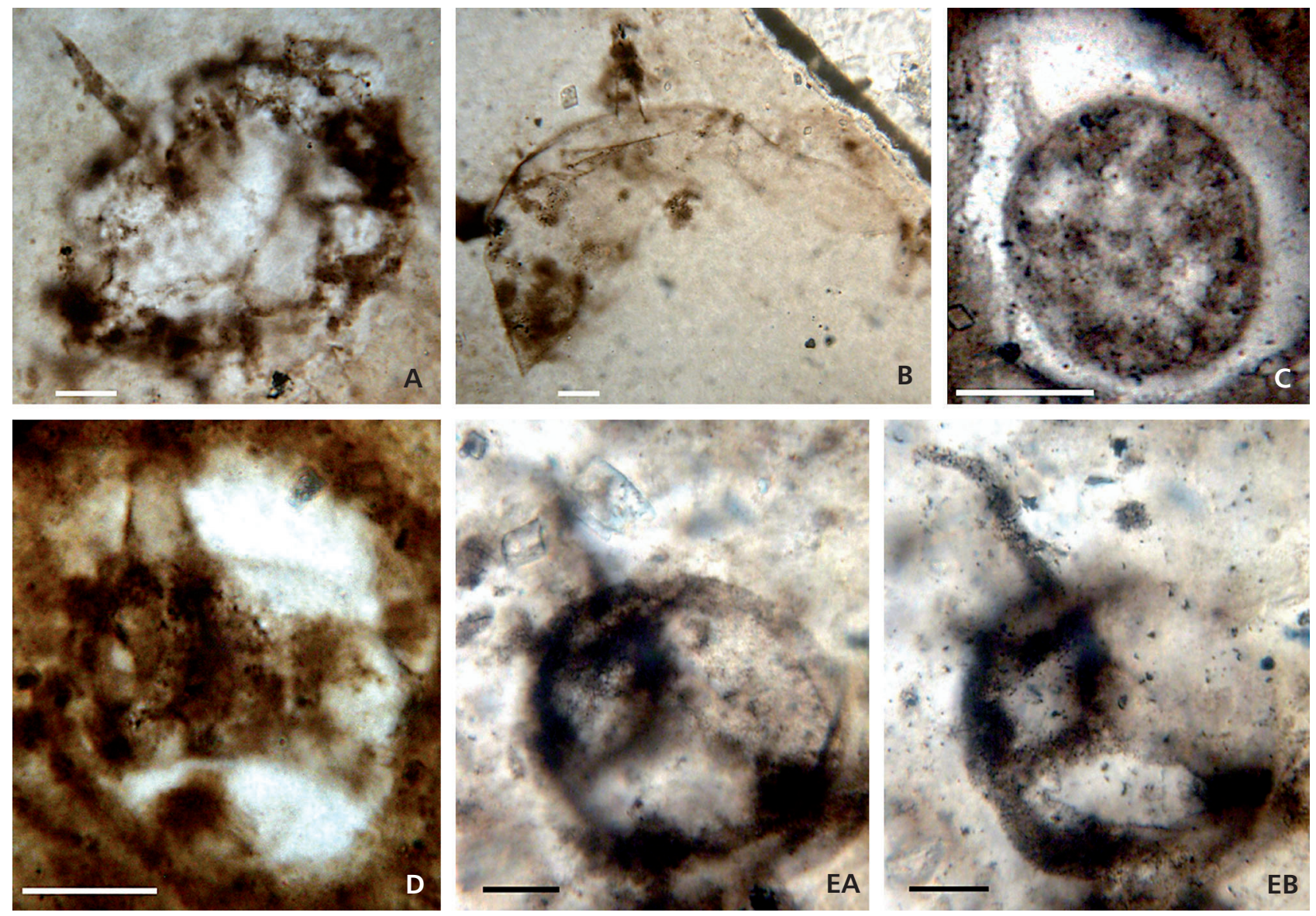

Figure 2. Ceratosphaeridium glaberosum Grey, 2005 from the Doushantuo Formation in Yangtze Gorges. - A - WFG367, thin section WFG80816-3-15, coordinates $17 \times 86$; B - WFG537, thin section WFG8421-72, coordinates 42.4 × 89.6; C - XFH383, thin section X71013-4-092, coordinates $31.6 \times 93.6$; D - WFG382, thin section WFG80816-3-23, coordinates $41.2 \times 97.8$; E - XFH340, thin section X71013-4-067, coordinates $41.8 \times 100.3, \mathrm{~EB}$ is a different focus of EA. Scale bars $=20 \mu \mathrm{m}$.

Member and Tanana Formation in the Officer Basin and the Pertatataka Formation in the Amadeus Basin, South Australia. It is characterized by a medium to large vesicle, circular to subcircular in outline (probably originally spherical), bearing a single, prominent, hollow, tapering process, with closed distal end and communicating proximally with thevesicle cavity. The vesicle wall is single-layered, thin, and either granular or smooth. The two species, Ceratosphaeridium mirabile (type species) and C. glaberosum, are distinguished by whether or not they have grana on the surface of the vesicle. In the case of $C$. mirabile, the whole surface of the vesicle is covered by small, densely scattered grana, but the grana are not present on the process. By contrast, both the vesicle wall and process of $C$. glaberosum is smooth (Grey 2005).

Two distinctive palynofloras, the Ediacaran leiosphere palynoflora (ELP) and the Ediacaran complex acritarch palynoflora (ECAP), were identified in the Officer and Amadeus basins, South Australia (Grey et al. 2003, Grey 2005). The ECAP was subdivided into four assemblage zones and each assemblage zone is based on three key species. In ascending order, they are (1) Appendisphaera barbata-Alicesphaeridium medusoidum-Gyalosphaeridium pulchrum Assemblage Zone; (2) Tanarium conoideumSchizofusa risoria-Variomargosphaeridium litoschum Assemblage Zone; (3) Tanarium irregular-Ceratosphaeridium glaberosum-Multifronsphaeridium pelorium Assemblage Zone; and (4) Ceratosphaeridium mirabile-Distosphaera australica-Apodastoidas verobturatus Assemblage Zone (Grey et al. 2003, Grey 2005). Obviously, the genus Ceratosphaeridium plays an important role in the third and fourth assemblage zones.

So far, nine specimens of Ceratosphaeridium have been identified from thin sections of chert nodules in the Chinese successions (Fig. 2). Their vesicles are medium to large, and circular to subcircular in outline. The diameters vary from 42 to $230 \mu \mathrm{m}$ (average $128 \mu \mathrm{m}$, nine measurements). Vesicle walls are generally thin, single-layered with smooth surfaces and a single, prominent process. The process is hollow, tapering with closed ends and freely communicating with the vesicle cavity. The length of processes varies from 15 to $78 \mu \mathrm{m}$ (average $39 \mu \mathrm{m}$, nine 

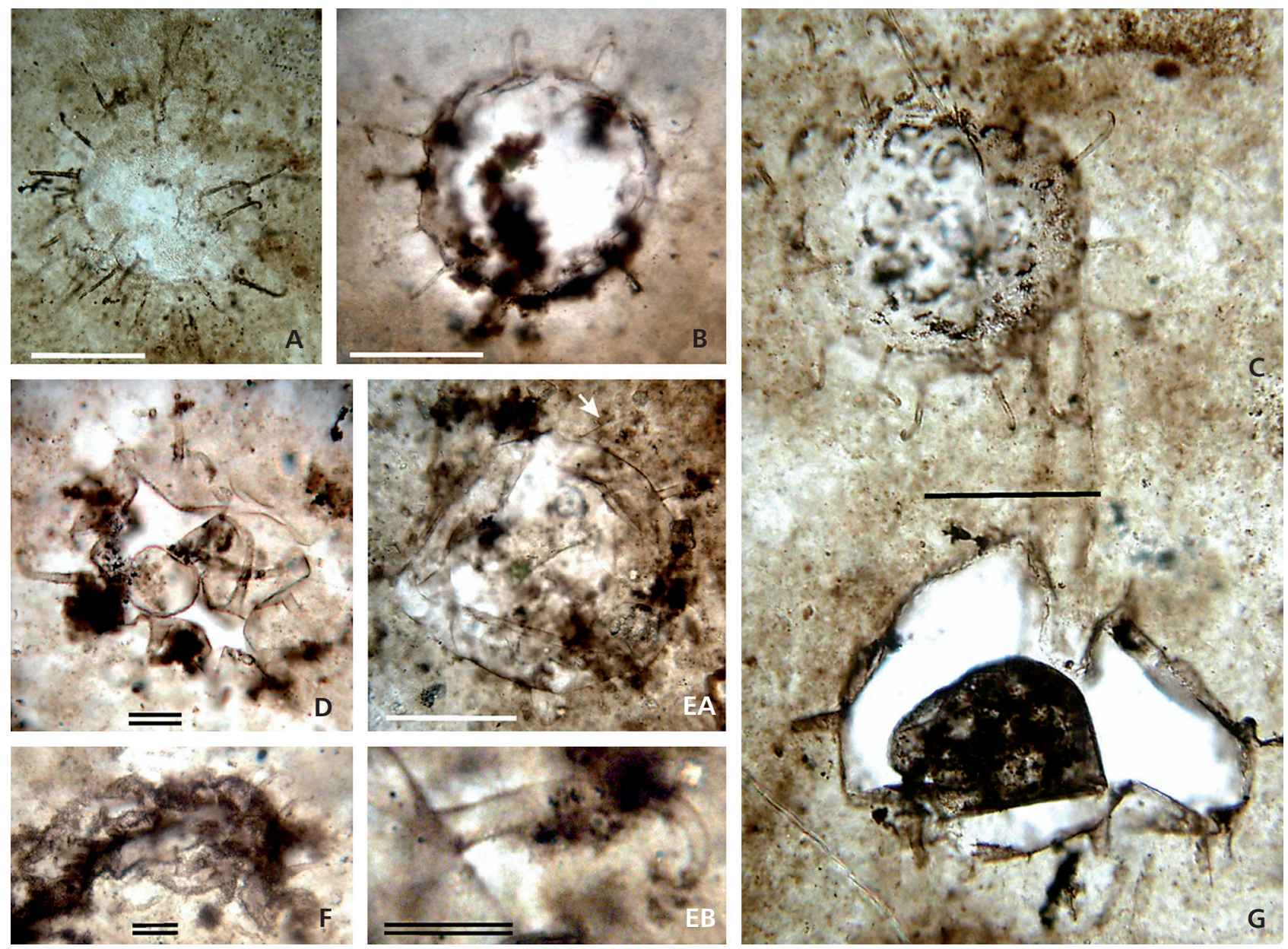

Figure 3. Acritarchs associated with Ceratosphaeridium glaberosum Grey, 2005 from the Doushantuo Formation in Yangtze Gorges. - A-C - Tanarium anozos Willman \& Moczydłowska, 2008. A - WFG095, thin section WFG8421-8b, coordinates 47.5 × 87.7; B - NP III 069, thin section NP III b-8, coordinates $39.4 \times 91.9 ; 3$, NP III 052, thin section NP III b-4, coordinates $32.5 \times 93.2$. $・$ D-G - Tanarium conoideum Kolosova, 1991. D - NP III 168, thin section NP III b-23, coordinates $51.9 \times 99.9$; E - WFG423, thin section WFG80816-3-31, coordinates $34.5 \times 88$, EB is an enlarged view of marked with arrow in EA; F - XFH332, thin section X71013-4-061, 40.5 × 99.5; G - NP III 053, thin section NP III b-4, coordinates $32.5 \times 93.2$. Single and double bars represent $100 \mu \mathrm{m}$ and $25 \mu \mathrm{m}$, respectively.

measurements), with a base of $4.5-13 \mu \mathrm{m}$ in diameter (average $11.8 \mu \mathrm{m}$, nine measurements). These characteristics of all specimens are similar to Ceratosphaeridium glaberosum Grey, 2005 found from the Officer and Amadeus basins, South Australia (Grey 2005, Willman \& Moczydłowska 2008). Thus, all specimens from the Doushantuo Formation are assigned to Ceratosphaeridium glaberosum.

\section{The inter-continental biostratigraphic correlation of Ceratosphaeridium}

Two different acritarch assemblages were identified in the Ediacaran Doushantuo Formation of the Yangtze Gorges, South China, which separately appear in the Member and lower Member III (Yin et al. 2009). The carbon isotope composition $\left(\delta^{13} \mathrm{C}_{\text {carb }}\right)$ of the Doushantuo Formation shows three prominent negative excursions (EN1-EN3) separa- ted by generally positive values (EP1 and EP2) (Zhou \& Xiao 2007, Zhu et al. 2007). Two microfossil assemblages of the Doushantuo Formation in the Yangtze Gorges appear generally within the positive values parts (EP1 and EP2) respectively. The lower assemblage is characterized by Tianzhushania and a high diversification of large acanthomorphic acritarchs. The upper assemblage is distinguished from the lower assemblage by (1) being devoid of $\mathrm{Ti}$ anzhushania; (2) by the first occurrence of abundant 50-150 $\mu \mathrm{m}$, smooth-walled spherical microfossils; (3) by the first occurrence of diverse new acanthomorphic acritarchs (they will be reported later); and (4) the first occurrence of tubular microfossils, such as Sinocyclocylicus guizhouensis (Yin et al. 2009). In particular, Tanarium is a key taxon in the upper assemblage.

The lack of easily identifiable and geographically widespread fossils, however, makes it relatively difficult for Ediacaran biostratigraphic correlation between South 
China and other continents, although recent studies show that acritarchs and other microfossils are abundant in the Ediacaran rocks and their potential for biostratigraphic subdivision and correlation is becoming increasingly important (Yin 2001, Grey 2005, Willman et al. 2006, Willman \& Moczydłowska 2008).

Ceratosphaeridium glaberosum is a key species of ECAP in the Officer and Amadeus basins, South Australia, and it mainly appears in the upper ECAP (in both the Tanarium irregulare-Ceratosphaeridium glaberosumMultifronsphaeridium pelorium and Ceratosphaeridium mirabile-Distosphaera australica-Apodastoidas verobturatus assemblage zones; Grey 2005). The discovery of Ceratosphaeridium glaberosum from Member III (upper acritarch assemblage) of the Doushantuo Formation in the Yangtze Gorges, South China suggests that this taxon is widely distributed and has potential for inter-continental correlation. In addition, the acritarchs Tanarium conoideum, T. anozos (Fig. 3) and some new taxa (they will be described in a separate paper) have also been found in the Member III of the Doushantuo Formation. Specimens of both Tanarium conoideum and T. anozos are very abundant in chert nodules; in particular, 77 specimens of $T$. anozos have been observed in one thin section (thin section NP IIIb-23). The taxon Tanarium conoideum is a widely distributed species and has found from the Vendian of the Siberian Platform (Moczydłowska 2005), and particularly in the Tanarium conoideum-Schizofusa risoria-Variomargosphaeridium litoschum Assemblage Zone of ECAP in South Australia (Grey et al. 2003, Grey 2005, Willman \& Moczydłowska 2008). Prior to this report, Tanarium anozos, which was established by Willman \& Moczydłowska (2008), was only found from the Tanana Formation (upper ECAP) in the Giles 1 drillhole of the Officer Basin, South Australia (Willman \& Moczydłowska 2008). Thus, the acritarch assemblage in Member III (upper microfossils assemblage) of the Doushantuo Formation in the Yangtze Gorges shows good correlation with the ECAP from South Australia. The fossil assemblage can correlated with lower microfossil assemblage in the Yangtze Gorges may be missing in South Australia.

\section{Conclusions}

Ediacaran large acanthomorphic acritarchs are known from several basins, including South China, South Australia, East European Platform, Siberia, northern India and Svalbard (Yin \& Li 1978, Yin 1987, Knoll \& Ohta 1988, Knoll 1992, Yin \& Liu 1988, Yin 1999, Vidal 1990, Zang \& Walter 1992, Moczydlowska et al. 1993, Tiwari \& Knoll 1994, Yuan \& Hofmann 1998, Zhang et al. 1998, Xiao 2004, Grey 2005, Veis et al. 2006, Willman et al. 2006, Willman \& Moczydlowska 2008, Zhou et al. 2007, Vorobeva et al. 2009a, b), and their potential for biostratigraphic subdivi- sion and global correlation is becoming increasingly important although they can be limited by facies control, taphonomic biases, and taxonomic problems (Grey et al. 2003, Grey 2005, Willman \& Moczydlowska 2008, Yin et al. 2009, McFadden et al. 2009, Vorobeva et al. 2009a). The discovery of Ceratosphaeridium glaberosum and some other typical taxa of ECAP from the upper acanthomorphic acritarch assemblage in the Yangtze Gorges suggests that only upper Doushantuo acanthomorphic acritarch assemblage is present in South Australia, and lower Doushantuo acanthomorphic acritarch assemblage (the key taxon is Tianzhushania) is missing from South Australia. Despite the absence of the lower zone, some large acanthomorphic acritarchs can be used as standard fossils for global biostratigraphic correlation of Ediacaran successions.

\section{Acknowledgments}

We thank Kathleen Grey for helping in fossil identification and Zhou Chuanming for discussion. This study was supported by National Natural Science Foundation of China (41172035) and China Geological Survey (121201120140 and 1212010911071).

\section{References}

Chen, M.E., XiaO, Z.Z. \& Yuan, X.L. 1994. A new assemblage of megafossils - Miaohe biota from Upper Sinian Doushantuo Formation, Yangtze Gorges. Acta Palaeontologica Sinica 33, 391-403.

Condon, D., Zhu, M.Y., Bowring, S., Wang, W., YAng, A.H. \& JiN, Y.G. 2005. U-Pb ages from the Neoproterozoic Doushantuo Formation, China. Science 308, 95-98. DOI 10.1126/science.1107765

EvitT, W.R. 1963. A discussion and proposals concerning fossil dinoflagellates, hystrichospheres and acritarchs. Proceedings of the National Academy of Sciences of the United States of America 49, 298-302. DOI 10.1073/pnas.49.3.298

Grey, K. 2005. Ediacaran palynology of Australia. Memoirs of Association of Australasian Palaeontologists 31, 1-439.

Grey, K., Walter, M.R. \& CAlver, C.R. 2003. Neoproterozoic biotic diversification: Snowball Earth or aftermath of the Acraman impact? Geology 31, 459-462.

DOI 10.1130/0091-7613(2003)031<0459:NBDSEO>2.0.CO;2

KNOLL, A.H. 1992. Vendian microfossils in metasedimentary cherts of the Scotia Group, Prins Karls Forland, Svalbard. Palaeontology 35(4), 751-774.

Knoll, A.H. \& Оhта, Y. 1988. Microfossils in metasediments from Prins Karls Forland, western Svalbard. Polar Research 6, 59-67. DOI 10.1111/j.1751-8369.1988.tb00581.x

Kolosova, S.P. 1991. Late Precambrian spiny microfossils from the eastern Siberian Platform. Algologiya 1(2), 53-59.

Liu, P.J., XIAO, S.H., Yin, C.Y., TAng, F. \& GaO, L.Z. 2009b. Silicified tubular microfossils from the upper Doushantuo Formation (Ediacaran) in the Yangtze Gorges area, South China. Journal of Paleontology 83(4), 630-633. DOI 10.1666/08-034R1.1

LiU, P.J., Yin, C.Y., GAO, L.Z., TANG, F. \& Chen, S.M. 2009a. New material of microfossils from the Ediacaran Doushantuo 
Formation in the Zhangcunping area, Yichang, Hubei Province and its zircon SHRIMP U-Pb age. Chinese Science Bulletin 54(6), 1058-1064. DOI 10.1007/s11434-008-0589-6

McFadden, K.A., XiaO, S.H., Zhou, C.M. \& Kowalewski, M. 2009. Quantitative evaluation of the biostratigraphic distribution of acanthomorphic acritarchs in the Ediacaran Doushantuo Formation in the Yangtze Gorges area, South China. Precambrian Research 173, 170-190.

DOI 10.1016/j.precamres.2009.03.009

MoczydŁowsKa, M. 2005. Taxonomic review of some Ediacaran acritarchs from the Siberian Platform. Precambrian Research 136, 283-307. DOI 10.1016/j.precamres.2004.12.001

MoczydŁowska, M., Vidal, G. \& Rudavskaya, V.A. 1993. Neoproterozoic (Vendian) phytoplankton from the Siberian Platform, Yakutia. Palaeontology 36, 495-521.

TAng, F., Yin, C.Y., Bengtson, S., Liu, P.J., Wang, Z.Q. \& GaO, L.Z. 2008. Octoradiate spiral organisms in the Ediacaran of south China. Acta Geologica Sinica 82(1), 27-34.

TANG, F., Yin, C.Y., Liu, Y.Q., WANG, Z.Q., Liu, P.J. \& GAO, L.Z. 2006. A new discovery of macroscopic fossils from the Ediacaran Doushantuo Formation in the Yangtze Gorges area. Chinese Science Bulletin 51(12), 1487-1493. DOI 10.1007/s11434-006-2007-2

Tiwari, M. \& KNOLL, A.H. 1994. Large acanthomorphic acritarchs from the Infrakrol Formation of the Lesser Himalaya and their stratigraphic significance. Journal Himalayan Geology $5,193-201$.

Veis, A.F., Vorobeva, N.G. \& Golubkova, E.Y. 2006. The early Vendian microfossils first found in the Russian Plate: Taxonomic composition and biostratigraphic significance. Stratigraphy and Geological Correlation 14(4), 368-385. DOI $10.1134 / \mathrm{S} 0869593806040022$

VIDAL, G. 1990. Giant acanthomorph acritarchs from the upper Proterozoic in southern Norway. Palaeontology 33(2), 287-298.

Vorobeva, N.G., Sergeev, V.N. \& Knoll, A.H. 2009a. Neoproterozoic microfossils from the northeastern margin of the East European platform. Journal of Palaeontology 83, 161-196. DOI 10.1666/08-064.1

Vorobeva, N.G., Sergeev, V.N. \& Knoll, A.H. 2009b. Neoproterozoic microfossils from the margin of the East European Platform and the search for a biostratigraphic model of lower Ediacaran rocks. Precambrian Research 173, 163-169. DOI 10.1016/j.precamres.2009.04.001

WilLman, S. \& MoczydŁowsKa, M. 2008. Ediacaran acritarch biota from the Giles 1 drillhole, Officer Basin, Australia, and its potential for biostratigraphic correlation. Precambrian Research 162, 498-530. DOI 10.1016/j.precamres.2007.10.010

Willman, S., MoczydŁowska, M. \& Grey, K. 2006. Neoproterozoic (Ediacaran) diversification of acritarchs - a new record from the Murnaroo 1 drillcore, eastern Officer Basin, Australia. Review of Palaeobotany and Palynology 139, 17-39. DOI 10.1016/j.revpalbo.2005.07.014

XIAO, S.H. 2004. New multicellular algal fossils and acritarchs in Doushantuo chert nodules (Neoproterozoic; Yangtze Gorges, South China). Journal of Paleontology 78, 393-401.

DOI 10.1666/0022-3360(2004)078<0393:NMAFAA >2.0.CO;2

XiaO, S.H., Yuan, X.L., Steiner, M. \& Knoll, A.H. 2002. Macroscopic carbonaceous compressions in a terminal Proterozoic shale: a systematic reassessment of the Miaohe biota, South China. Journal of Paleontology 76, 345-374.

YIN, C.Y. 1999. Microfossils from the upper Sinian (Late Neoproterozoic) Doushantuo Formation in Changyang, Western Hubei, China. Continental Dynamics (Institute of Geology, CAGS) 4(2), 1-18.
YIN, C.Y. 2001. Discovery of Papillomembrana compta in Weng'an, Guizhou with discussion on the correlation of the large acanthomorphic acritarchs and the age of the Doushantuo Formation. Journal of Stratigraphy 25(4), 253-258.

Yin, C.Y. \& LiU, G. 1988. Micropaleofloras, 170-180. In Zнао, Z.Y. et al. (eds) The Sinian System of Hubei. China University of Geosciences Press, Wuhan.

Yin, C.Y., Liu, P.J., Chen, S.M., TANG, F., GAO, L.Z. \& Wang, Z.Q. 2009. Acritarch biostratigraphic succession of the Ediacaran Doushantuo Formation in Yangtze Gorges. Acta Palaeontologica Sinica 48(2), 146-154.

Yin, C.Y., Liu, P.J., Chen, S.M., TANG, F., GAO, L.Z. \& Wang, Z.Q. 2009. Acritarch biostratigraphic succession of the Ediacaran Doushantuo Formation in the Yangtze Gorges. Acta Palaeontologica Sinica 48, 146-152.

Yin, C.Y., TANG, F., Liu, Y., GaO, L.Z., Liu, P.J., Xing, Y., Yang, Z., WAN, Y. \& WANG, Z.Q. 2005. U-Pb zircon age from the base of the Ediacaran Doushantuo Formation in the Yangtze Gorges, South China: constraint on the age of Marinoan glaciation. Episodes 28(1), 48-49.

YIN, L.M. 1987. Microbiotas of latest Precambrian sequences in China, 415-494. In Nanjing of Geology and Palaeontology, Academia Sinica (ed.) Stratigraphy and palaeontology of systemic boundaries in China, Precambrian-Cambrian boundary (1). Nanjing University Publishing House, Nanjing.

Yin, L.M. \& Li, Z.P. 1978. Pre-Cambrian microfloras of southwest China, with reference to their stratigraphical significance. Memoir of Nanjing Institute of Geology and Palaeontology, Academia Sinica 10, 41-108.

Yin, L.M., Zhu, M.Y., Knoll, A.H., Yuan, X.L., Zhang, J.M. \& Hu, J. 2007. Doushantuo embryos preserved inside diapause egg cysts. Nature 446(5), 661-663.

Yuan, X.L. \& Hofmann, H.J. 1998. New microfossils from the Neoproterozoic (Sinian) Doushantuo Formation, Weng'an, Guizhou Province, Southwestern China. Alcheringa 22, 189-222. DOI 10.1080/03115519808619200

ZANG, W.L. \& WaLter, M.R. 1992. Late Proterozoic and Early Cambrian microfossils and biostratigraphy, Amadeus Basin, central Australia. Memoris of Association of Australasian Palaeontologists 12, 1-132.

Zhang, S.H., Jiang, G.Q., Zhang, J.M., Song, B., Kennedy, M.J. \& Nicholas, C.B. 2005. U-Pb sensitive high-resolution ion microprobe ages from the Doushantuo Formation in south China: Constraints on late Neoproterozoic glaciations. Geology 33(6), 473-476. DOI 10.1130/G21418.1

Zhang, Y., Yin, L.M., XIAO, S.H. \& Knoll, A.H. 1998. Permineralized fossils from the Terminal Proterozoic Doushantuo Formation, South China. Palaeontological Society Memoir 50, 1-52.

Zhоu, C.M. \& XIAO, S.H. 2007. Ediacaran $\delta^{13}$ C chemostratigraphy of South China. Chemical Geology 237, 107-126. DOI 10.1016/j.chemgeo.2006.06.021

Zhou, C.M., Xie, G.W., McFadden, K., Xiao, S.H. \& Yuan, X.L. 2007. The diversification and extinction of Doushantuo-Pertatataka acritarchs in south China: causes and biostratigraphic signification. Geological Journal 42, 229-262. DOI $10.1002 / \mathrm{gj} .1062$

Zhu, M.Y., Zhang, J.M. \& YANG, A.H. 2007. Integrated Ediacaran (Sinian) chronostratigraphy of South China. Palaeogeography, Palaeoclimatology, Palaeoecology 254, 7-61. DOI 10.1016/j.palaeo.2007.03.025

ZHU, W.Q. \& CHEN, M.E. 1984. On the discovery of macrofossils algae from the late Sinian in the eastern Yangtze Gorges, South China. Acta Botanica Sinica 26(5), 558-560. 